\title{
INCREASE VARIATION ON POTATO 'GRANOLA’ USING GAMMA RAY IRRADIATION
}

\author{
Muhammad Ibadullah, Ida Ayu Astarini*, and Eniek Kriswiyanti \\ Biology Study Program, Faculty of Mathematics and Natural Sciences, \\ Udayana University, Bali, Indonesia \\ *Corresponding author: iaastarini@unud.ac.id
}

\begin{abstract}
Potato is one of the main carbohydrate sources around the world, including Indonesia. Potato production in Bali generally does not use good quality of potato seed, causing disease infection and reduce productivity. An alternative effort to produce high quality potato is by induce mutation of tuber using gamma ray irradiation. This study aims to find out percentage of survival after irradiation of 'Granola' potato shoots and determine the post-irradiation potato growth and productivity. This research was conducted at Laboratory of Central Application of Isotope and Irradiation (PAIR), Pasar Jumat, Batan, Jakarta and UPT BBITPH Bedugul, Bali. Planting materials were early generation (G0) potato seed tubers. This study employ completely randomized factorial design with one factor, i.e. irradiation doses of $0,20 \mathrm{gy}$ and $40 \mathrm{~Gy}$. Variable observed included percentage of shoots survive, and variations in production. Results showed that 20 Gy was the best dose to increase tuber production.
\end{abstract}

Keywords: Solanum tuberosum, mutation, variation of growth, variation of production

\section{INTRODUCTION}

Potato (Solanum tuberosum L.) is one priority commodity for development in Indonesia. Potato can be used as alternative source of carbohydrates. Central potato production in Indonesia is Pangalengan (West Java), Dieng highlands (Central Java), Kerinci (Jambi), Curup (Bengkulu) Pasuruan (East Java) and Baturiti Bedugul (Bali).

Obtaining high quality potatoes seed is still a problem in potato production center in several areas in Indonesia. Besides the limited supply of quality potatoes seed, the availability of national certified potatoes seed is also still rare. In 2008, there's only $6 \%$ seed avalaible from 128.6 thousand tons needed per year (Direktoral Jenderal Hortikultura, 2008; Muhibuddin et al., 2009).

The procurement of superior quality potatoes seed have been done, and has been set as a superior national research by national research council since 2004 (Dewan Riset Nasional, 2008). Agriculture research and development center in each region has put an effort to produce early generation high quality seed to support national food security policy (Balitbangtan, 2008). 
The effort to produce superior quality seeds can be carried out with the method of introduction, selection, hybridization and mutation. A mutation is a change that occurs in the genetic material of living beings at random and unannounced, and also the cause of the formation of the variations of living organisms that are passed down from generation to the next generation. Mutations can occur spontaneously and through the process of induction (Balitbangtan, 2008). The effort of obtaining seeds with the method of mutation induction is a promising breakthrough in plant breeding program because the process can be generated mutant with new properties that can be advantageous for plants breeding results.

Mutation induction can be done physically and chemically (Soedjono, 2003; Mba, 2013). Mutation induction in irradiation with gamma rays is the most frequently performed the induction. This can be seen from 1.585 varieties mutants that were released around the world since $1985,64 \%$ of them are developed by dir ect gamma rays mutations induction (Ahloowalia et al., 2004; Foster, 2012).

Previous research on application of gamma rays shows that irradiation of gamma rays can cause changes in morphological, physiological and biochemistry, as well as generate faster vegetative growth, flowering early and more products on the low doses. This has been reported in orchids and carnations with a doses of 31.88 Gy (Aisha, 2006), improving germination of seed and growth of seedling of forest plants at doses of $10 \mathrm{~Gy}$ (Akshatha et al., 2013), increase life percentage of Impatiens Balsamina L. at doses 10 Gy (Defiani et al., 2017), increased growing speed of Phylodendron at a doses of $10 \mathrm{~Gy}$ (Meliana, 2008) and increased growth speed of potato tuber 'Atlantic' and 'Granola' at a doses of 30 Gy (Suharjo et al., 2010). This research was done as an attempt to produce new variations which are favourable for plant breeding, and the results are expected to improve the quality and the quality of production of potatoes for the farmers.

\section{MATERIALS AND METHODS}

The research was held from October 2017 until February 2018. Plant materials in this research are early generation tubers (Generation $0=\mathrm{G} 0$ ) aged three months, provided by UPT BBITPH, Bedugul, Bali. Gamma rays irradiation exposure to potato seed tubers was done at Laboratory of Central Application of Isotope and Irradiation (PAIR), Pasar Jumat, Batan, Jakarta. The source of irradiated gamma rays from rate ionization Cobalt $60\left({ }^{60} \mathrm{Co}\right)$ is a gamma chamber $4000 \mathrm{~A}$ 
radiator, Irpasena type (made in India). Material that does not given treatment irradiated (0 Gy) also taken to BATAN to ensure that the treatment is equal to all materials in this research.

Post irradiation potato seeds were grown in Kembang Merta, UPT Balai Benih Induk Tanaman Pangan dan Hortikultura (UPT BBITPH), Bedugul, Bali. Tubers are grown in the glass houses, in media consisting of a mixture of soil, compost (produce by Guama), NPK (1:1:1) fertilizer.

RESULTS AND DISCUSSION

Percentage of Plant survive and Growth Rate
This study employed Completely Randomized Design with one factor i.e. gamma ray irradiation doses, with three doses of irradiation, i.e. 0, $20 \mathrm{~Gy}$ and $40 \mathrm{~Gy}$. Each treatment consists of nine replicates, each of it has four sub units, so there were 108 tubers being used. Observation starts from the tubers grown until the tubers ready to harvest. Variable observed were percentage of plant survived, time of emergence, plant height, and harvest age, number of tubers, weight and diameter of tubers.

Table 1. Variable Observed After Gamma Irradiation Treatment

\begin{tabular}{lccc}
\hline \multirow{2}{*}{ Observation variable } & \multicolumn{3}{c}{ Iradiation doses } \\
\cline { 2 - 4 } & $\mathbf{0 ~ G y}$ & $\mathbf{2 0 ~ G y}$ & $\mathbf{4 0 ~ G y}$ \\
\hline Emergence (days) & 7 & 7 & 14 \\
Plant height (cm) at 12 WAP & $47.2^{\mathrm{c}} \pm 20.3$ & $38.7^{\mathrm{b}} \pm 14.2$ & $25.6^{\mathrm{a}} \pm 11.1$ \\
Plant survive (\%) at 12 WAP & 86.7 & 93.4 & 50.0 \\
Harvest age (days) & 85 & 91 & 100 \\
\hline
\end{tabular}

Means followed by the same letter are not significantly different at 5\% level.

This experiment shows that exposing seed tuber to 20 Gy Gamma ray has resulted on $93.4 \%$ seed survival. Previous research by Al-Saladi (2000) also revealed doses of gamma ray give positive effect to the plant. Suharjo et al. (2010) conducted the same experiment using the same method of radiating gamma ray at 10 of $30 \mathrm{~Gy}$ and revealed that it increased the percentage of potato sprout. 
Plant received irradiation are more field (Fig. 1). On the other hand, irradiated vigorous, healthy and pest free compared to plants are growing faster and better despite the controlled plants at 72 day after planting environment that support pest and desease. The (DAP). A few pest and disease appears on the infected plant growth was disturbed causing it controlled plants but not on the irradiated plant to grow fewer tubers. These conditions are due (Fig. 1), such as apids (Aphis sp.), Thrips sp. to the pest and disease infected to the plants, malformation of leaves and dry patches disturbing the physiology of the plants itself. (Altenaria solani) were also observed in the
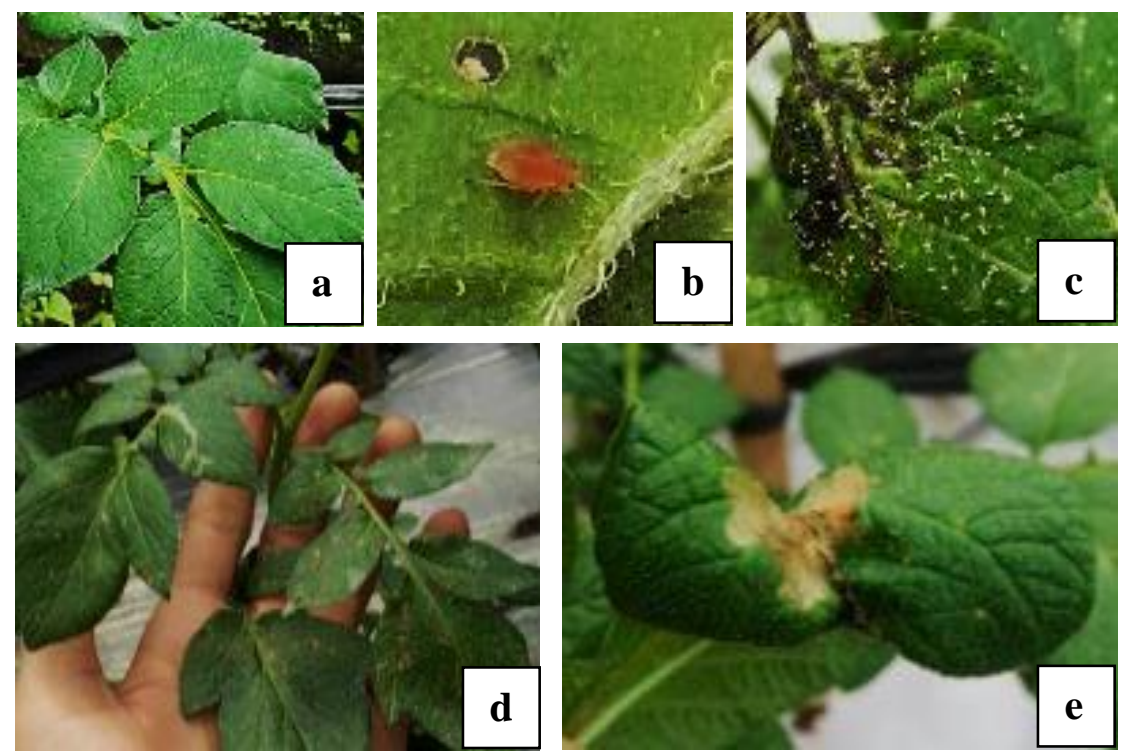

Fig. 1. Pest and diseases observed on potato plants, a) Healthy Leaves,

b) Aphids, c) Dry Patches, d) Malformation, e) Thrips Pest

Doses of 40 Gy significantly inhibit The use of 40 Gy decreased the growth buds growth, slows the growth of the plants performance of the irradiated plant, compared and delay harvest (Table 1). Suharjo et al. to control plants. Same result was reported by (2010) described that gamma ray irradiation at Went et al (2001) that tubers with high the doses around 40 to $50 \mathrm{~Gy}$, significantly irradiation doses experienced chromosomal inhibit the growth of the roots and no buds are mutation and decreased the productivity rate growing when plant were explosed to $60 \mathrm{~Gy}$. significantly. 


\section{Productivity Rate}

Tabel 2. Harvest Parameter After Gamma Irradiation Treatments

\begin{tabular}{lccc}
\hline \multirow{2}{*}{ Observation Variable } & \multicolumn{3}{c}{ Iradiation Doses } \\
\cline { 2 - 4 } & $\mathbf{0 ~ G y}$ & $\mathbf{2 0 ~ G y}$ & $\mathbf{4 0 ~ G y}$ \\
\hline Numbers of Tubers & 186 & 182 & 94 \\
Average of Each Tubers & $7.1^{\mathrm{b}} \pm 0.8$ & $6.5^{\mathrm{a}} \pm 0.9$ & $6.3^{\mathrm{a}} \pm 0.8$ \\
Weight of Total Tubers $(\mathrm{g})$ & 5354 & 6667 & 2563 \\
Average of Weight $(\mathrm{g})$ & $28.8^{\mathrm{a}} \pm 17.5$ & $36.6^{\mathrm{b}} \pm 27.1$ & $27.3^{\mathrm{a}} \pm 19.3$ \\
Average of Diameter $(\mathrm{cm})$ & $3.1^{\mathrm{a}} \pm 1.1$ & $4.0^{\mathrm{b}} \pm 1.4$ & $3.0^{\mathrm{a}} \pm 0.9$ \\
\hline
\end{tabular}

Means followed by the same letter are not significantly different at $5 \%$ level.

Interaction between irradiation doses against tubers have significant impact on the growth of the tubers, expressed by the number of tubers, the number average of each tubers, total weight of tubers, and average of weights and tubers diameter.

Tuber seeds received 20 Gy irradiation show best productivity (Fig. 2). Tubers expose to a dose of 20 Gy having the highest value of the total weight of tuber, average of tubers weight and average of diameter (Table 2). Zainudin (2016) also revealed that tubers which were produced after exposure to $20 \mathrm{~Gy}$ dose have superior quality.

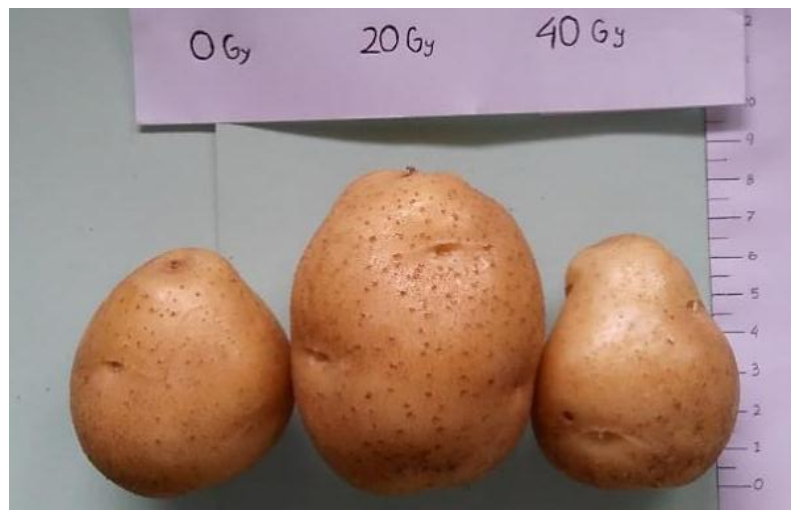

Fig. 2. Harvested Tuber Performance after Gamma Iradiation on various doses

Irradiation doses of 40 Gy decrease productivity of tubers, both seed tubers and tubers for consumption. The number of tubers produced on dose 40 Gy decreased almost $50 \%$ compared to control doses and the weight of tubers does not reach $50 \%$ from control doses. Doses 40 Gy tend to decrease productivity of 
tubers up to $50 \%$ compared to control plant (Table 2). The result showed that doses 40 Gy give negative effect on potato plants.

\section{CONCLUSIONS}

It can be concluded that exposing potato tubers to various gamma irradiation increased variation. Exposure of early generation potato tubers (G0) to 20 Gy gamma irradiation dose able to increase potato poductivity $(25 \%)$ compared to control plants, while at $40 \mathrm{~Gy}$, productivity was decreased around 50\% compared to control plants.

\section{ACKNOWLEDGMENT}

The authors gratefully thank Mr. Usman Kris Joko Suharjo, Mr. I Made Suartana and Dr. Ni Made Armini Wiendi for their help and suggestion during this study.

\section{REFERENCES}

Ahlowalia, B. S., Maluszynski, M., \& Nichterlein, K. (2004). Global Impact of Mutation Derived Varieties. Euphytica. 135, 187 - 204.

Aisyah, S. I. (2006). Mutasi Induksi Fisik dan Pengujian Stabilitas Mutan yang Diperbanyak secara Vegetatif pada Anyelir (Dianthus caryophyllus Linn.). Institut Pertanian Bogor. (Disertasi). Tidak dipublikasikan.

Akshatha, C., Somashekarappa, K. R., \& Souframanien, J. (2013). Effect of gamma irradiation on germination, growth, and biochemical parameters of Terminalia arjuna Roxb. Radiat Prot Environ. 36:38, 44.

Al-Saladi, B., Ayyoubi, Z., \& Jawdat, D. (2000). The effect of gamma irradiation on potato microtuber production in vitro. Plant Cell Organ Cult, 81, 183 187.

Azzamy. (2015). Hama dan Penyakit Tanaman Kentang. Access 25 Augst 2017, from http/l. HAMA\% 20 PENYAKIT\% 20Utama\% 20Tanaman\% 20Kentang.html.

Badan Penelitian dan Pengembangan Pertanian. (2008). Pedoman Pengusulan Hibah Penelitian KKP3T 2009. Badan Litbang Pertanian. Jakarta.

Brunt, A. A. (2001). 'The main viruses infecting potato crops', Loebenstein $\mathrm{G}$, Berger, PH, Brunt, AA \& Lawson RH, (eds.), Virus and virus-like diseases of potatoes and production of seedpotatoes, Kluwer Academic Publishers, Dordrecht (NL), pp $65-7$.

Defiani, M. R., Astarini, I. A., \& Kriswiyanti, E. (2017). Oryzalin and Gamma Radiation Induced Polyploidization in Garden Balsam Plants (Impatiens Balsamina L.) In Vitro. Curent Agriculture Research Journal Vol. 5(1): $1-5$.

Dewan Riset Nasional. (2008). Arah Kebijakan Riset Nasional. Dewan Riset Nasional. Jakarta.

Dianawati, M., Ilyas, S., Wattimena, G. A., \& Susila, A. D. (2013). Produksi Umbi Kentang secara Aeroponik melalui Penentuan Dosis Optimum Pupuk Daun Nitrogen. J. Hort, 23(1), 47 - 55.

Direktorat Jenderal Hortikultura. (2008). Produksi Benih Kentang menurut Kelas, Direktorat Jenderal Hortikultura. Jakarta.

Forster, B. P. (2012). Plant mutagenesis in crop improvement: basic terms and applications. In: Shu, Forster BP, 
Nakagawa H. editor. Plant Mutation Breeding and Biotechnology. Food and Agriculture Organization of the United Nations; Rome, Italy, Austria (AT): FAO/IAEA. p. $9-20$.

Mba, C. (2013). Induced mutations unleash the potentials of plant genetic resources for food and agriculture. Agronomy. 3:200 -231 .

Meliana, R. (2008). Pengaruh Mutasi Induksi dengan Iradiasi Sinar Gamma terhadap Keragaman Dua Spesies Philodendron (Philodendron bipinnatifidium cv. Crocodile teeth dan p. xanadu). Program Studi Pemuliaan Tanaman dan Teknologi Benih, Fakultas Pertanian Institut Pertanian Bogor. (Skripsi). Tidak dipublikasikan.

Muhibuddin, Zakaria, A. B., Lisan, E., \& Baharuddin. (2009). Peningkatan Produksi dan Mutu Benih Kentang Hasil Kultur In Vitro melalui Introduksi Sistem Aeroponik dengan Formulasi NPK. Prosiding Seminar Nasional Pekan Kentang 2008, Puslitbang Hortikultura, Badan Litbang Pertanian, Kementerian Pertanian.1: 102 - 105.

Samadi, B. (2007). Kentang dan Analisis Usaha Tani. Kanius Press. Yogyakarta.

Soedjono, S. (2003). Aplikasi Mutasi Induksi dan Variasi Somaklonal dalam Pemuliaan Tanaman. Jurnal Litbang Pertanian. 22(2), 71 - 78.

Suharjo, U. K. J., Herison, C., \& Fahrurrozi. (2010). Keragaman Tanaman Kentang Varietas Atlantik dan Granola di Dataran Medium (600 mdpl) Bengkulu Pasca Iradiasi Sinar Gamma. Akta Agrosia. 13(1), 82 - 88.

Wendt, S. N. A., Petes, J. A., de Oliveria, A. C., Babrowksi, V. L., de Dosta, F. L. C., S. dos S. Mandrugo \& Vighi, I. L. (2001). Characterization of potato cultivars Macaca, obtained from Gamma-Irradiated Plants. J. New Seeds 3(20), $17-37$.
Zainudin, Z. (2016). Tips Membeli Bibit Kentang yang Berkualitas Bagus. Access 25 Augst 2017, from http//.Tips\%20Membeli\%20Bibit\%20K entang\%20yang\%20Berkualitas\%20Ba gus.html. 